\title{
Controls of picophytoplankton abundance and composition in a highly dynamic marine system, the Northern Alboran Sea (Western Mediterranean)
}

\author{
Ana L. Amorim, Pablo León ${ }^{1}$, Jesús M. Mercado*, Dolores Cortés, Francisco Gómez, Sebastien Putzeys, \\ Soluna Salles, Lidia Yebra
}

Instituto Español de Oceanografía, Centro Oceanográfico de Málaga, Puerto Pesquero s/n, Fuengirola, 29074 Málaga, Spain

\section{A R T I C L E I N F O}

\section{Article history:}

Received 22 July 2015

Received in revised form 9 February 2016

Accepted 24 February 2016

Available online 27 February 2016

\section{Keywords:}

Prochlorococcus

Synechococcus

Cyanobacteria

Mediterranean Sea

Flow cytometry

Upwelling

\begin{abstract}
A B S T R A C T
The Alboran Sea is a highly dynamic basin which exhibits a high spatio-temporal variability of hydrographic structures (e.g. fronts, gyres, coastal upwellings). This work compares the abundance and composition of picophytoplankton observed across the northern Alboran Sea among eleven cruises between 2008 and 2012 using flow cytometry. We evaluate the seasonal and longitudinal variability of picophytoplankton on the basis of the circulation regimes at a regional scale and explore the presence of cyanobacteria ecotypes in the basin. The maximal abundances obtained for Prochlorococcus, Synechococcus and picoeukaryotes $\left(12.7 \times 10^{4}\right.$,

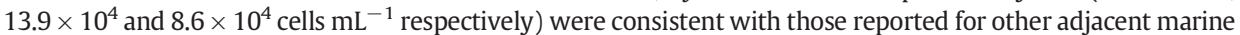
areas. Seasonal changes in the abundance of the three picophytoplankton groups were highly significant although they did not match the patterns described for other coastal waters. Higher abundances of Prochlorococcus were obtained in autumn-winter while Synechococcus and picoeukaryotes exhibited a different seasonal abundance pattern depending on the sector (e.g. Synechococcus showed higher abundance in summer in the west sector and during winter in the eastern study area). Additionally, conspicuous longitudinal gradients were observed for Prochlorococcus and Synechococcus, with Prochlorococcus decreasing from west to east and Synechococcus following the opposite pattern. The analysis of environmental variables (i.e. temperature, salinity and inorganic nutrients) and cell abundances indicates that Prochlorococcus preferred high salinity and nitrate to phosphate ratio. On the contrary, temperature did not seem to play a role in Prochlorococcus distribution as it was numerically important during the whole seasonal cycle. Variability in Synechococcus abundance could not be explained by changes in any environmental variable suggesting that different ecotypes were sampled during the surveys. In particular, our data would indicate the presence of at least two ecotypes of Synechococcus: a summer ecotype widely distributed in the whole Alboran Sea and a winter ecotype adapted to lower temperature and higher nutrient concentration whose growth is favoured in the eastern sector.
\end{abstract}

(c) 2016 Elsevier B.V. All rights reserved.

\section{Introduction}

The autotrophic picoplankton (i.e. smaller than $2 \mu \mathrm{m}$; Sieburth, 1979 ) is an important component of the phytoplankton community, which dominates over larger phytoplankton in vast areas of the open sea, contributing significantly to the oceanic primary production, particularly in oligotrophic waters (Agawin et al., 2000; Gutiérrez-Rodríguez et al., 2011; Silovic et al., 2011). Cyanobacteria of the genera Prochlorococcus and Synechococcus are normally the most abundant picophytoplankton cells, although eukaryotes belonging to the classes Prasinophyceae, Pelagophyceae, Prymnesiophyceae and

\footnotetext{
* Corresponding author.

E-mail address: jesus.mercado@ma.ieo.es (J.M. Mercado).

1 Present address: Marine Scotland Science, Marine Laboratory Aberdeen, PO Box 101, 375 Victoria Road, Aberdeen AB11 9DB, UK.
}

Chrysophyceae can also become numerically important (Vaulot et al., 2008). In the open sea, high abundances of Prochlorococcus have been reported in deeper layers of stratified oligotrophic waters (Christaki et al., 2001; Li et al., 1993; Partensky et al., 1999; Zohary et al., 1998). By contrast, Synechococcus grows optimally in nutrient-enriched and mixed waters (Campbell et al., 1994). In the Mediterranean Sea, a chiefly oligotrophic basin, the dominance of picoplankton over larger phytoplankton in offshore areas has been reported by different authors (Denis et al., 2010; Siokou-Frangou et al., 2010; Uitz et al., 2012). However, horizontal distribution of Prochlorococcus and Synechococcus reveals complex patterns that do not fit completely those described for other oceanic areas. For instance, Prochlorococcus becomes abundant in surface waters of the northwestern Mediterranean Sea in a variety of habitats including not only offshore stratified waters but also mixed coastal waters (Vaulot et al., 1990). Dominance of Synechococcus has been reported in upper layers of oligotrophic Mediterranean areas 
during stratification periods (Marty et al., 2002). This distribution probably results from the presence of different ecotypes of Prochlorococcus and Synechococcus growing optimally at specific conditions of temperature, light and nutrients. In fact, Mella-Flores et al. (2011) found that two low-light adapted clades of Prochlorococcus were segregated spatially between the northern and southern parts of the Mediterranean Sea. In the same study, Synechococcus clades dominating in Mediterranean mesotrophic waters showed to be genetically distinguishable from the clades dominating low nutrient environments in the southern Mediterranean Sea.

The longitudinal distribution of autotrophic picoplankton in the Alboran Sea (the westernmost sub-basin in the Mediterranean Sea) also indicates the presence of complex patterns that apparently do not respond to variability in a single environmental factor. The Atlantic water jet that penetrates into the Alboran Sea throughout the Strait of Gibraltar feeds two quasi-permanent anticyclonic gyres, which occupy the entire central part of the western and eastern sub-basins (Minas et al., 1991; Tintoré et al., 1991). At the north edges of both gyres, the geostrophic fronts promote the upwelling of subsurface water. These upwellings are frequently enhanced by favourable winds blowing along the northwestern coast (Mercado et al., 2012; Sarhan et al., 2000). This physical framework allows distinguishing three geographical sectors based on the distribution of the main hydrographic structures and water masses in the basin: i) Gibraltar Strait, characterized by the water exchanges between the Mediterranean Sea and the Atlantic Ocean; ii) the western sector, driven by the presence of the western anticyclonic gyre (WAG) and the coastal upwelling and the incoming Atlantic jet (salinity < 36.6); iii) the eastern sector, dominated by the eastern anticyclonic gyre (EAG) and the gradient between Atlantic (fresher) and Mediterranean (saltier) waters (Allen et al., 2001; Lafuente et al., 1998; Renault et al., 2012; Sarhan et al., 2000). Jacquet et al. (2002) found that Synechococcus dominated the picophytoplankton community in the EAG core, while Prochlorococcus dominated in the gyre edge (occupied by nutrient-depleted Mediterranean water). On the other hand, Reul et al. (2005) reported the dominance of Synechococcus at stations located in the north edge of the WAG although the abundances of both Prochlorococcus and Synechococcus increased to the centre of the gyre. Based on their results, Jacquet et al. (2002) attributed the distribution pattern of Synechococcus in the eastern Alboran Sea to the nutrient horizontal gradients in agreement with the paradigm that Synechococcus grows optimally in nutrient-enriched and mixed waters (Li, 1994). However, Reul et al. (2005) concluded that Synechococcus abundance in the western Alboran Sea was negatively correlated with nutrient concentrations. These divergent observations may indicate the presence of ecotypes of Synechococcus inhabiting the western and eastern sub-basins of the Alboran Sea, adapted to the large variations in bio-physiochemical conditions that characterize the basin. In this work this hypothesis is tested by analysing the spatio-temporal variability of the composition and abundance of the picophytoplankton communities across the Northern Alboran Sea. These analyses are based on data obtained during several oceanographic surveys carried out between 2008 and 2012.

\section{Materials and methods}

Eleven oceanographic cruises were carried out between 2008 and 2012 in the NW Alboran Sea on board R/V Francisco de Paula Navarro, R/V Odón de Buen and R/V Emma Bardán (Table 1). In overall, 37 stations from the Bay of Algeciras to the Bay of Almeria (western and eastern margins of the basin, respectively) were sampled (Fig. 1; note that not all the stations were sampled during each survey). Sampling stations were mainly located in coastal waters (depth lower than $100 \mathrm{~m}$ ), but also included the continental shelf (100-200 m depth; AG3, AG5, M3, M13-M15, AL6) and off-shore areas (deeper than 200 m; AG4, AG6, M7, M8, M16, M19-20, AL7-9).
Table 1

Cruise dates, sampling stations and geographic sectors (BA, Bay of Algeciras; WS, western sector; ES, eastern Sector). See Fig. 1 for a more detailed description of the position of the sampling stations.

\begin{tabular}{llll}
\hline Cruise & Date of sampling & Sampling stations & $\begin{array}{l}\text { Geographic } \\
\text { sector }\end{array}$ \\
\hline 0508 & 9-14 May 2008 & M1-M6 & WS \\
0908 & 9-12 Sep. 2008 & M1, M7-M20, & WS \\
0909 & 23-25 Sep. 2009 & M14-M17; AL1-AL3 & WS, ES \\
0710 & 07-14 July 2010 & AG1-AG4; M7-M15; AL1-AL9 & BA, WS, ES \\
1210 & 28-Nov.-02 Dec. 2010 & M14-15; AL1 & WS, ES \\
0311 & 19-21 March 2011 & M12-M14; AL1-AL4 & WS, ES \\
0811 & 30-July-04-Aug. 2011 & M12-M14; AL1-AL3 & WS, ES \\
1211 & 23 Nov.-02 Dec. 2011 & AG2-AG5; M14-M17; AL1-AL4 & BA, WS, ES \\
0312 & 06-11 March 2012 & AG2-AG3; M14-M17; AL1-AL4 & BA, WS, ES \\
0412 & 16-21 April 2012 & M14-M17; AL1-AL3 & WS, ES \\
0712 & 07-15 July 2012 & AG2-AG4; M14-M17; AL1-AL4 & BA, WS, ES \\
\hline
\end{tabular}

At each station, a CTD (Seabird 25) cast was completed to obtain information of the physical structure of the water column. The euphotic zone depth (Ze, depth at which the downwelling PAR irradiance is reduced to $1 \%$ of its value at the surface) was estimated from the Secchi disc depth (ZSD) by assuming that the PAR attenuation coefficient is 1.7 of the inverse ZSD (Preisendorfer, 1986). Water samples were collected at fixed depths $(0,10,20,30,50,75$ and $100 \mathrm{~m})$ using 5 L Niskin bottles. At coastal stations and over the continental shelf the number of sampled levels depended on the topography. To determine inorganic nutrient concentration, two $10 \mathrm{~mL}$ sub-samples of seawater were collected at each depth and immediately frozen at $-20^{\circ} \mathrm{C}$. Concentrations of nitrate plus nitrite, nitrite, phosphate and silicate were analysed by segmented flow analysis using a Bran-Luebbe AA3 autoanalyser, following the methods described in Ramírez et al. (2005). Note that the concentration of ammonia was not available for all cruises and has not been included for comparative reasons.

In addition, 0.5-1 L of seawater was filtered through Whatman GF/F filters and frozen aboard until analysed at the laboratory. Chlorophyll a concentration ( $\mathrm{chl} a$ ) was determined by spectrophotometry after extraction in $90 \%$ acetone overnight at $4-5{ }^{\circ} \mathrm{C}$.

To analyse picophytoplankton abundance and composition, $5 \mathrm{~mL}$ of seawater was preserved with glutaraldehyde ( $1 \%$ f.c.) and immediately frozen in liquid nitrogen (Vaulot et al., 1989). The samples were analysed using a Becton Dickinson FACScan flow cytometer. The analysis was performed based on the orange and red fluorescence signals together with the forward-light scatter (FSC). The latter allows a better estimation of the size of the scattering particle than the side scattered light (SSC), which is mainly associated with granularity (Petersen et al., 2012). This analysis allowed the identification of Prochlorococcus, Synechococcus and eukaryotic picoplankton as the main components of the autotrophic picoplankton community. The FSC BD TrueCOUNT Tubes were used to determine absolute counts.

Cell carbon biomass was estimated from picophytoplankton cell biovolume following Morel et al. (1993) for Prochlorococcus, Kana and Glibert (1987) for Synechococcus and Verity et al. (1992) for picoeukaryotes. Cell biovolumes of Prochlorococcus, Synechococcus and picoeukaryotes in the northwestern Mediterranean Sea were assumed to be $0.128,0.449$ and $1.33 \mu^{3}$ cell $^{-1}$, respectively (Ribes et al., 1999).

To investigate the longitudinal patterns of variability in picophytoplankton distribution, the data were grouped into three west-east geographical sectors: Bay of Algeciras (BA), western sector (WS), eastern sector (ES; Fig. 1). This clustering is consistent with the geographic distribution of hydrographic structures and the marked gradient of circulation regimens present in the Alboran Sea (see introduction). Seasonal means of abundance of the three picophytoplankton cell groups were calculated for the three geographical sectors in order to determine annual variability patterns (note that there were not available data for 
(a)

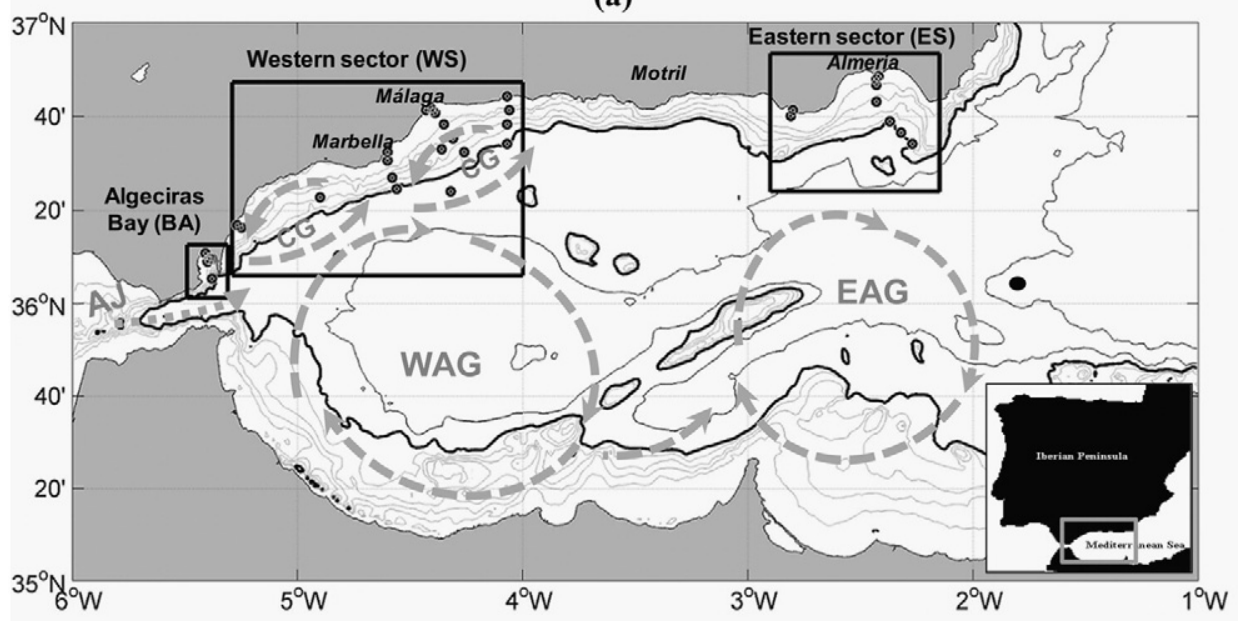

(b)

(c)

Algeciras Bay (BA)

Western sector(WS)

(d)

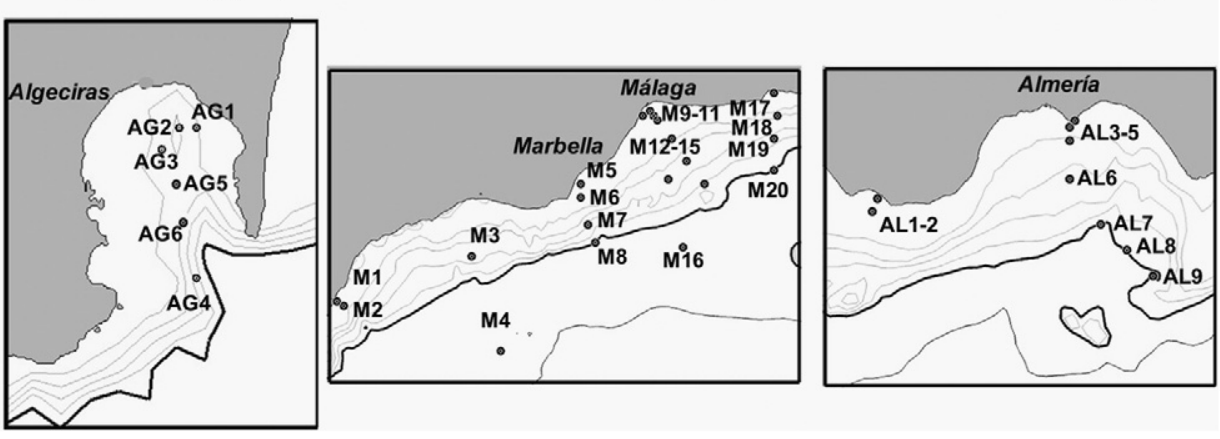

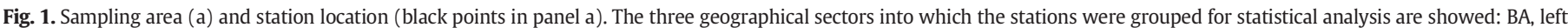

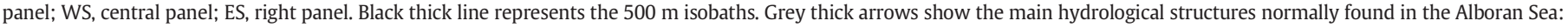

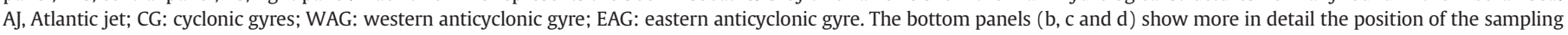
stations in the three sectors.

spring in BA). Data were grouped seasonally according to the period of the year in which each sample was collected: winter (January-March), spring (April-June), summer (July-September) and autumn (OctoberDecember). For each area, the statistical significance of the differences in abundance and biomass among seasons were tested with one-way ANOVA at $p=0.05$. Statistical significance of the differences among the three areas for each season was also researched with one-way ANOVA. Similar comparisons were done with the hydrological variables (temperature and salinity), nutrient and chl $a$ concentration. Additionally, Pearson's correlation analyses between picophytoplankton biomass and chl a concentration were performed. Previously data were logtransformed to meet statistical requirements for normality and homogeneity of variances. Normality was evaluated from the normal probability plot of the residuals of each variable. Homogeneity of variances was tested with a Levene's test. The assumptions of the ANOVA were satisfied by all the variables.

A factorial (Discriminant Function) analysis was conducted to investigate the relationship between variation patterns of the environmental variables and picophytoplankton populations. The Discriminant Function Analysis allows determining which combination of variables better discriminate between groups of observations. The variables used in the analysis were temperature, salinity, nutrients, nitrate:phosphate molar ratio, chl a concentration and cell abundances. Because of the diversity of values and ranges all data were standardized to a mean of 0 and standard deviation of 1 for each geographical sector prior to conducting the factorial analysis. Only the data obtained within the euphotic layer were used. The software package Statistica 7.1 (Statsoft, Inc. 1984-2005) was used for the statistical analyses.

\section{Results}

3.1. Variability in abundance and composition of the autotrophic picoplankton communities

Fig. 2 shows the distribution of the abundances of Prochlorococcus, Synechococcus and picoeukaryotes along the optical depth for the whole analysed dataset (i.e. 581 samples). The optical depth refers to the depth of irradiance levels in the water column according to the attenuation experienced by the downwelling irradiance at that level (Bukata et al., 1995). In other words, it corresponds to different physical depths but the same overall diminution of irradiance, and can be derived from the PAR vertical attenuation coefficient. In our work, optical depths have been estimated from the amount of surface irradiance remaining at each specific depth as derived from the corresponding PAR vertical attenuation coefficient calculated from ZSD (see material and methods). Most samples (75\%) were collected within the first optical layer (euphotic layer, EL), where the maximal abundances of the three cell groups were obtained $\left(12.7 \times 10^{4}\right.$, $13.9 \times 10^{4}$ and $8.6 \times 10^{4}$ cells $\mathrm{mL}^{-1}$ for Prochlorococcus, Synechococcus and picoeukaryotes, respectively). In this layer, picoeukaryotes were the most abundant group in $45 \%$ of the samples, while Prochlorococcus dominated only in $14 \%$ of the observations. Below EL (deep layer, DL), the abundance of Synechococcus and picoeukaryotes decreased by 3.2 and 2.3 times respectively, while the decrease of Prochlorococcus abundance was comparatively lower (1.5 times). Consequently, the percentage of Prochlorococcus-dominated samples in DL was higher than in EL. In terms of carbon biomass, picoeukaryotes, Synechococcus and 

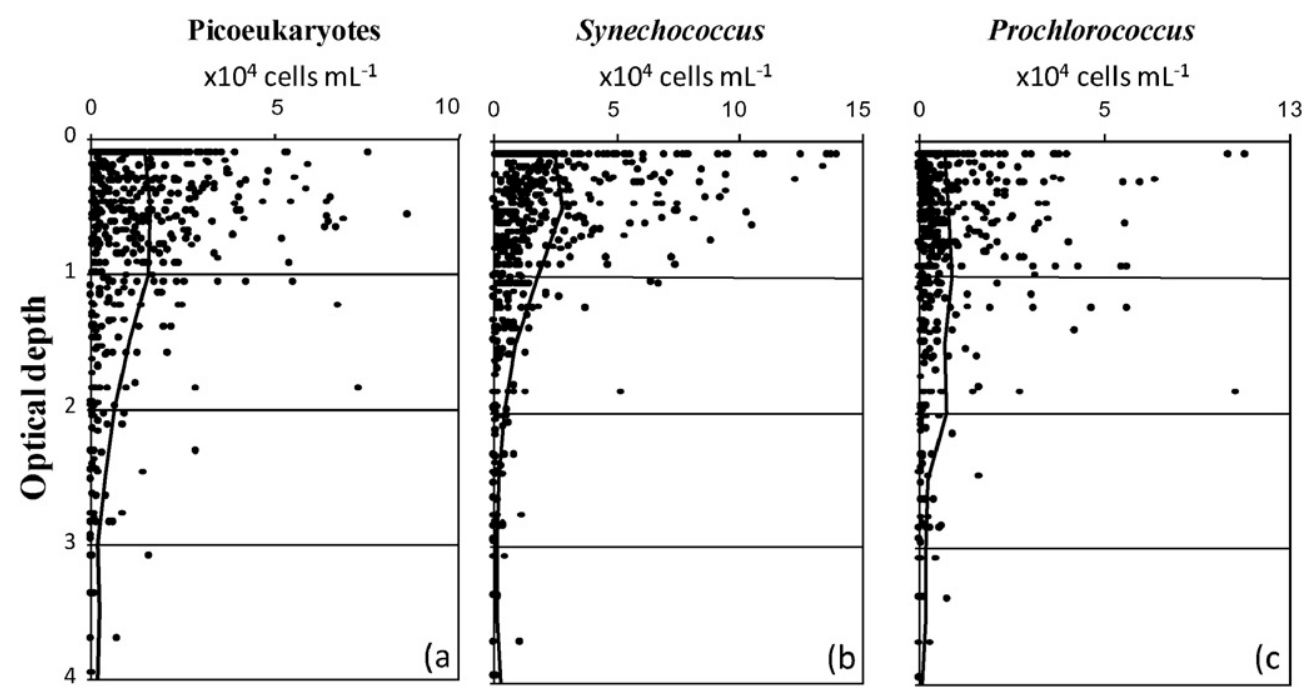

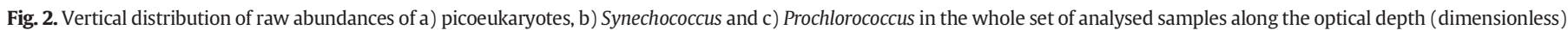
The trend lines fitted to the distribution of raw abundances are shown as black lines.

Prochlorococcus accounted for $64 \%, 28 \%$ and $6-11 \%$ of the total picophytoplankton biomass in EL, respectively.

EL-averaged abundance of Prochlorococcus was significantly higher in BA while Synechococcus showed higher concentrations in ES (Fig. 3, dark bars). In contrast, picoeukaryotes were more abundant in BA and WS than in ES. The seasonal analysis showed a highest abundance of Prochlorococcus during autumn in the three geographical sectors, although this annual maximum was comparatively more pronounced in BA. The temporal patterns of Synechococcus and picoeukaryotes showed significant differences among sectors. For instance, Synechococcus lowest values were obtained in BA in winter, coinciding with the annual period of maximum abundance in ES. Similarly, picoeukaryotes annual variability revealed an inverse pattern between BA and ES, where a concomitant increase/decrease of cell abundance was obtained from winter to autumn, respectively. This group also showed significant higher abundances in WS during summer.

Dominance patterns of picophytoplankton groups also differed among geographical sectors, even showing opposite longitudinal trends. Thus, dominance of Prochlorococcus and picoeukaryotes (estimated as the percentage of samples dominated by those groups) was higher in BA than in ES (Fig. 4), where Synechococcus showed a higher dominance. Differences among groups were not restricted to sectors, but also extended to seasonal analysis. Prochlorococcus showed a significant lower dominance during summer along the entire basin, as well as during winter-spring in ES. On the contrary, its dominance was more frequent for winter and autumn than for spring and summer in BA and WS. It is worth noting that not a single sample collected in ES for winter was dominated by Prochlorococcus. In this sector, the lowest dominance of Synechococcus was obtained for spring when picoeukaryotes were the dominant cell group. The latter were more dominant in BA and WS for summer.

\subsection{Relationship between hydrological variability and shifts in the communities}

Seasonal means of the environmental variables calculated for the study sectors are showed in Table 2 . As expected, temperature was lower in winter and spring and higher in summer for the three sectors. The annual cycle amplitude (i.e. the difference between annual maximum and minimum) was higher in ES. The later also showed higher salinity values for all seasons, being summer the period with fresher waters in WS and ES, and autumn in BA. Temporal differences among sectors were also observed for the Secchi disc depths, which showed deeper values during summer-autumn in BA, spring in WS and autumn in ES. Secchi depths indicated deeper euphotic layers in ES for most of the annual cycle, except for WS where the deepest layer was observed in spring. Nitrate concentration showed a strong seasonal variation among regions with the highest values generally obtained in WS, except for summer when were higher in BA and ES. The lowest levels coincided with winter, summer and autumn in ES, WS and BA respectively. In contrast, phosphate did not describe a clear seasonal cycle apart from WS where the mean concentration was almost double in spring and autumn compared to winter and summer. Due to the annual changes in nitrate and phosphate concentrations, N:P molar ratio (note that the concentration of ammonia was not included) varied strongly in all sectors. It was higher than the Redfield ratio (16:1) in BA and WS during the first part of the annual cycle (i.e. winter and spring), and lower during summer and autumn. On the contrary, ES showed relatively high N:P ratio also for autumn. Average concentrations of silicate were generally lower in ES than in the study westernmost sectors where silicate seemed to follow a seasonal cycle, with higher values in WS during winter-spring and in BA for summer-autumn. Our dataset shows chl $a$ annual maxima obtained during winter in WS and during spring in ES, when the shallowest euphotic layers (see Secchi disc depths) were observed in each sector. Similarly the highest value in BA corresponded to winter. In this period chl $a$ average concentration was about 2 and 6-fold higher than in WS and ES respectively, coinciding with similar or even lower nitrate and phosphate concentrations than in those sectors.

The results of the factorial analysis performed with the physicalchemical variables and cell abundances are shown in Fig. 5. Three factors were found to be significant. The first factor (F1) extracted explained $35 \%$ of variability. Temperature contributed negatively to F1 while nutrient concentrations and salinity contributed positively (Fig. 5a). Most of the samples collected in summer for all sectors had negative scores of F1 (Fig. 6). Therefore, F1 discriminated the samples collected in summer period under strong stratification and relatively low nutrient concentration. The second factor (F2) explained $18 \%$ of variability. Chl $a$, salinity, N:P ratio and Prochlorococcus abundance contributed positively to F2 while phosphate did negatively (Fig. 5a). Most ES samples collected during winter and autumn had positive scores for F2 while most samples collected in WS during spring and autumn had negative scores. Additionally, F2 discriminated clearly the samples of BA collected during winter. Accordingly, the samples obtained during the most productive annual periods in each sector were discriminated by F2. These samples featured relatively high salinity and N:P ratio. Chl $a$ was the main variable contributing positively to the third factor (F3) that explained $12 \%$ of variability. Synechococcus abundance, N:P 
Prochlorococcus (cell $\mathbf{m L}^{-1}$ )
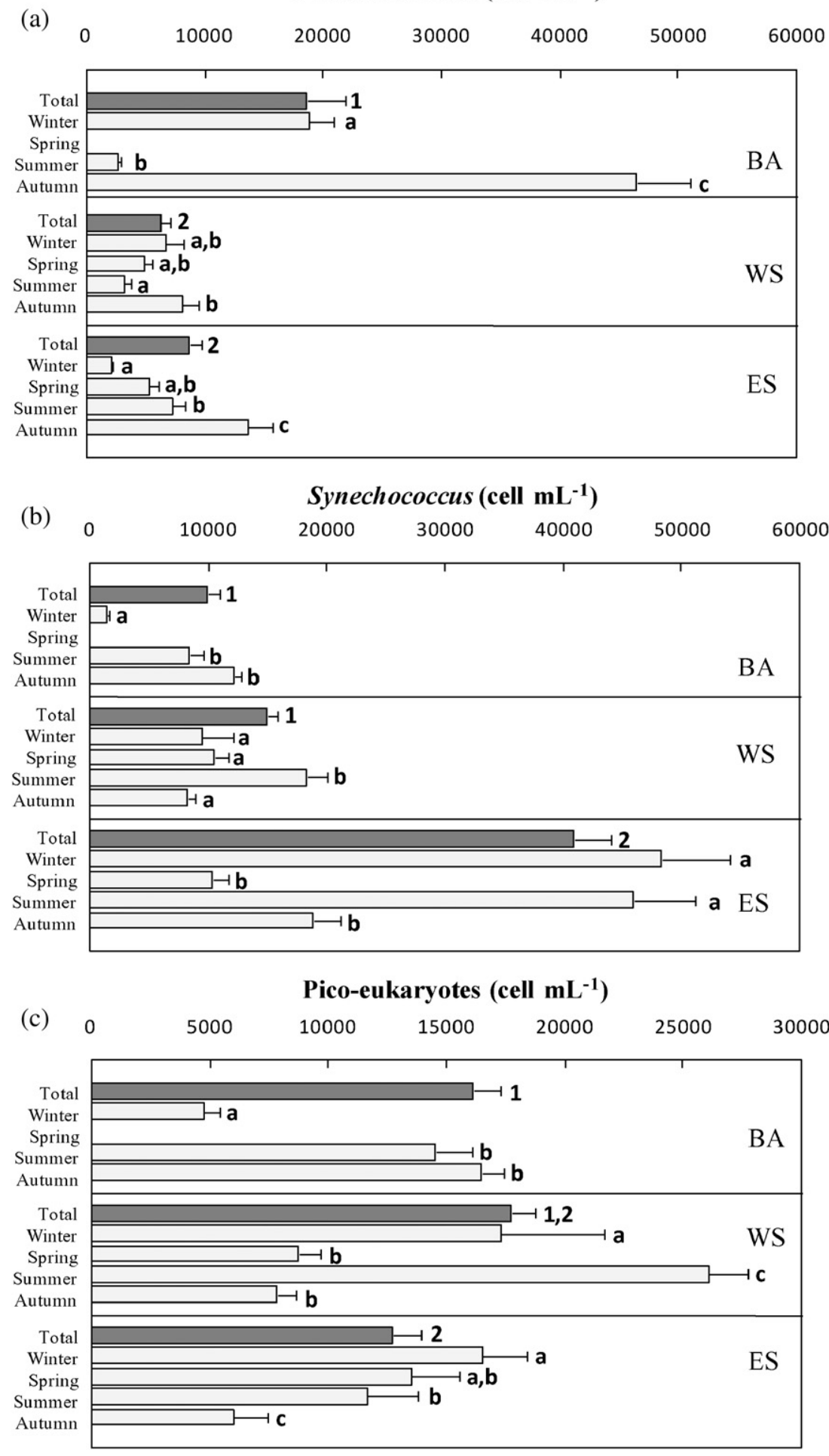

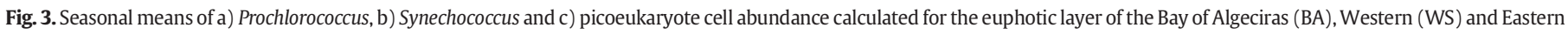

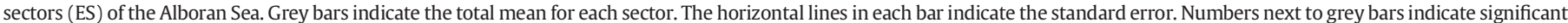

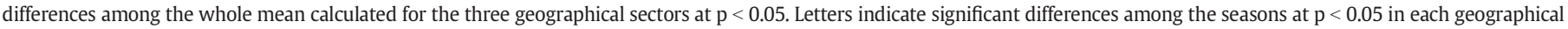
sector. Only the samples collected in the euphotic layer were used for these calculations.

ratio and temperature were the main variables that contributed negatively to F3 (Fig. 5b). Samples collected in ES during summer and autumn had the most negative scores for F3 while only a few samples collected in BA during summer had negative scores. F3 clearly separates picoeukaryotes and Synechococcus, with the first being more related to chl $a$ and the later to nitrate and salinity.

\section{Discussion}

\subsection{Physical framework}

The Surface Atlantic Water (SAW; S $<36.6$ ), which penetrates into the Alboran Sea throughout the Strait of Gibraltar, progressively mixes 


\section{Percentage of samples}

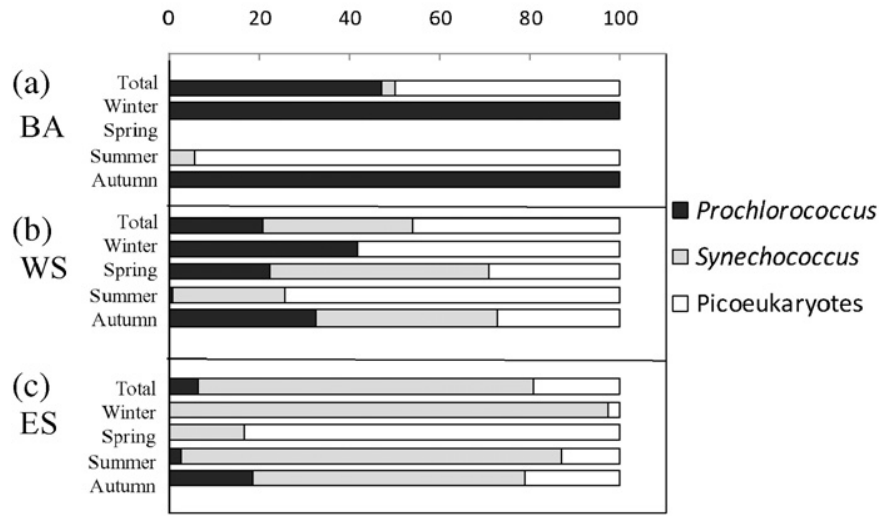

Fig. 4. Percentages of samples dominated by Prochlorococcus, Synechococcus and picoeukaryotes in each sector (total) and during each season: a) Bay of Algeciras (BA), b) Western (WS) and c) Eastern sectors (ES). Only the samples collected in the euphotic layer were used for those calculations.

with saltier and colder Mediterranean Water (MW; S > 37.5) during its displacement eastward (Lafuente et al., 1998; Mercado et al., 2007; Minas et al., 1991; Ramírez et al., 2005; Rodríguez et al., 1997, 1998; Sarhan et al., 2000). This mixture explains the occurrence of westernto-eastern gradients in surface temperature and salinity as a usual feature at the northern Alboran Sea (off Spanish coast). The physical framework described in this work is consistent with that pattern, showing a longitudinal gradient between the ES (with saltier waters) and BA-WS during most part of the seasonal cycle (only during summer the salinity showed no significant differences among sectors). Furthermore, temperature and salinity also showed a significant variability throughout the year within each geographical sector. Our data showed fresher and warmer waters corresponding to summer in the overall study area. According to previous studies, the summer period is featured by strong thermal stratification of the water column that hampers the re-supply of new nutrients towards the euphotic zone from the deep layer (Ramírez et al., 2005). This situation is also revealed by the structure of the first factor extracted from the factorial analysis (Fig. 5), which shows that seasonal warming and nutrient-depletion in the surface layer co-occurred in all sectors during summer, and to a lesser extent to some samples collected in other periods in each sector. Similarly, colder and saltier waters characterized the whole study area during the first part of the annual cycle, probably as a result of more intense mixing processes between SAW and MW. The presence of colder and saltier surface water cores is a common feature in the western coast of the Alboran Sea, where the coastal upwellings are often enhanced by favourable winds, especially during spring (Sarhan et al., 2000). These upwelling events fertilize the surface layer favouring the development of the annual phytoplankton bloom (Mercado et al., 2007; Ramírez et al., 2005). Our data suggest a temporal decoupling of the phytoplankton bloom between WS and ES, and show the first part of the annual cycle as the most productive period, particularly in BA. Such productivity is probably explained by the physical characteristics of BA, a semienclosed bay, which determines a circulation regime with relatively higher residence times of the water mass (Sánchez-Garrido et al., 2014). Our analysis (see Table 2) also indicates that the phytoplankton annual bloom in the whole study area occurs when nitrate availability increases (as inferred from N:P ratio), supporting a nutrient-driven phytoplankton growth as it has been previously reported for the northern Alboran Sea (Mercado et al., 2007; Reul et al., 2005).

\subsection{Variability of the picoplankton community in the Alboran Sea}

Picophytoplankton abundances reported in this work are consistent with published values for the Alboran Sea and other adjacent marine areas. Mean abundances of Prochlorococcus and Synechococcus are similar to those described by Reul et al. (2005) and Echevarría et al. (2009), while picoeukaryotes mean abundance is slightly higher than those obtained by Reul et al. (2005). Seasonal changes of Prochlorococcus abundance (higher in autumn-winter, Fig. 3) were in agreement with the annual variation in other coastal waters in the Cantabrian Sea (Calvo-Díaz et al., 2008), Atlantic and Pacific Oceans (Baltar et al., 2009; Liu et al., 2002), but contrary to those described in the subtropical North Atlantic where the annual peak occurs in summer (Durand et al., 2001; Worden et al., 2004). It is worth noting the almost absence of

Table 2

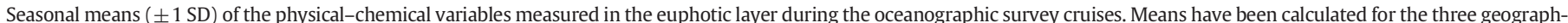

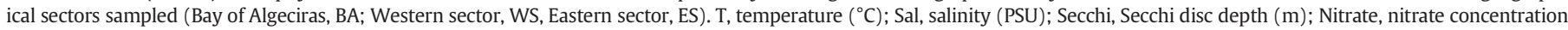

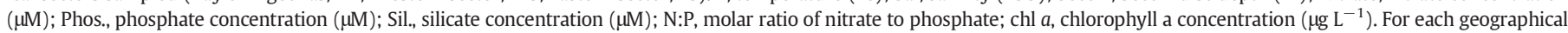
sector, the seasonal means were compared using a one-way ANOVA. In each cell, the means with different superscripts were significantly different at $\mathrm{p}<0.05$.

\begin{tabular}{|c|c|c|c|c|c|}
\hline & Geographical sector & Winter & Spring & Summer & Autumn \\
\hline & BA & $14.4 \pm 0.1 \mathrm{a}$ & - & $18.9 \pm 1.6 a$ & $16.5 \pm 0.2 \mathrm{a}$ \\
\hline \multirow[t]{3}{*}{$\mathrm{T}\left({ }^{\circ} \mathrm{C}\right)$} & WS & $14.5 \pm 0.5 a$ & $15.4 \pm 1.1 \mathrm{a}$ & $19.8 \pm 2.0 \mathrm{~b}$ & $15.9 \pm 1.4 b$ \\
\hline & ES & $14.8 \pm 0.2 \mathrm{a}$ & $13.9 \pm 0.2 b$ & $20.1 \pm 2.8 b$ & $18.7 \pm 0.7 c$ \\
\hline & BA & $37.3 \pm 0.1 \mathrm{a}, \mathrm{b}$ & - & $36.9 \pm 0.2$ & $36.7 \pm 0.1 \mathrm{a}$ \\
\hline \multirow[t]{3}{*}{ Sal (PSU) } & WS & $37.2 \pm 0.5 a$ & $37.5 \pm 0.7 a$ & $37.0 \pm 0.2$ & $37.2 \pm 0.5 b$ \\
\hline & ES & $37.5 \pm 0.1 b$ & $38.2 \pm 0.01 b$ & $37.0 \pm 0.3$ & $37.8 \pm 0.2 c$ \\
\hline & $\mathrm{BA}$ & $6.4 \pm 0.5 a$ & - & $11.3 \pm 2.5 a$ & $11.3 \pm 1.9 \mathrm{a}$ \\
\hline \multirow[t]{3}{*}{ Secchi (m) } & WS & $6.9 \pm 2.9 a$ & $21.8 \pm 11.6 a$ & $15.5 \pm 5.9 b$ & $9.4 \pm 4.2 \mathrm{a}$ \\
\hline & ES & $10.8 \pm 2.3 b$ & $10.0 \pm 0.0 \mathrm{~b}$ & $17.5 \pm 6.4 b$ & $18.1 \pm 5.1 b$ \\
\hline & BA & $1.0 \pm 0.5 a$ & - & $0.7 \pm 1.02 \mathrm{a}$ & $0.1 \pm 0.03 \mathrm{a}$ \\
\hline \multirow[t]{3}{*}{ Nitrate $(\mu \mathrm{M})$} & WS & $2.8 \pm 1.3 \mathrm{a}$ & $4.2 \pm 2.4$ & $0.4 \pm 1.0 \mathrm{~b}$ & $3.0 \pm 3.3 b$ \\
\hline & ES & $0.4 \pm 0.4 b$ & $2.9 \pm 0.9$ & $0.6 \pm 0.8 a, b$ & $1.1 \pm 0.5 a$ \\
\hline & $\mathrm{BA}$ & $0.04 \pm 0.01 \mathrm{a}, \mathrm{b}$ & - & $0.10 \pm 0.03$ & $0.08 \pm 0.01 \mathrm{a}$ \\
\hline \multirow[t]{3}{*}{ Phos. $(\mu \mathrm{M})$} & WS & $0.14 \pm 0.1 \mathrm{a}$ & $0.24 \pm 0.11 \mathrm{a}$ & $0.11 \pm 0.07$ & $0.3 \pm 0.2 b$ \\
\hline & ES & $0.04 \pm 0.02 b$ & $0.11 \pm 0.20 \mathrm{~b}$ & $0.10 \pm 0.04$ & $0.05 \pm 0.03 b$ \\
\hline & BA & $0.5 \pm 0.2$ & - & $0.9 \pm 0.5$ & $2.1 \pm 0.6 a$ \\
\hline \multirow[t]{3}{*}{ Sil. $(\mu \mathrm{M})$} & WS & $2.1 \pm 2.3$ & $2.6 \pm 1.2$ & $0.8 \pm 0.7$ & $2.0 \pm 1.5 \mathrm{a}$ \\
\hline & ES & $0.9 \pm 0.3$ & $1.7 \pm 0.4$ & $0.7 \pm 0.4$ & $1.0 \pm 0.4 b$ \\
\hline & BA & $23.8 \pm 12.8$ & - & $5.8 \pm 6.8 \mathrm{a}$ & $1.6 \pm 0.3 a$ \\
\hline \multirow[t]{3}{*}{$\mathrm{N}: \mathrm{P}$} & WS & $20.7 \pm 12.5$ & $17.3 \pm 10.1 \mathrm{a}$ & $5.5 \pm 7.3 b$ & $8.3 \pm 7.0 \mathrm{~b}$ \\
\hline & ES & $13.9 \pm 13.8$ & $25.8 \pm 5.9 b$ & $5.3 \pm 7.2 c$ & $29.8 \pm 20.5 c$ \\
\hline & BA & $5.9 \pm 0.4 a$ & - & $1.4 \pm 0.9 \mathrm{a}$ & $0.8 \pm 0.2$ \\
\hline \multirow[t]{2}{*}{$\operatorname{chl} a\left(\mu \mathrm{g} \mathrm{L}^{-1}\right)$} & WS & $2.8 \pm 0.7 \mathrm{~b}$ & $1.0 \pm 1.3$ & $0.6 \pm 0.6 b$ & $1.1 \pm 1.2$ \\
\hline & ES & $0.9 \pm 0.4 c$ & $2.4 \pm 1.04$ & $0.5 \pm 0.6 b$ & $0.8 \pm 0.4$ \\
\hline
\end{tabular}



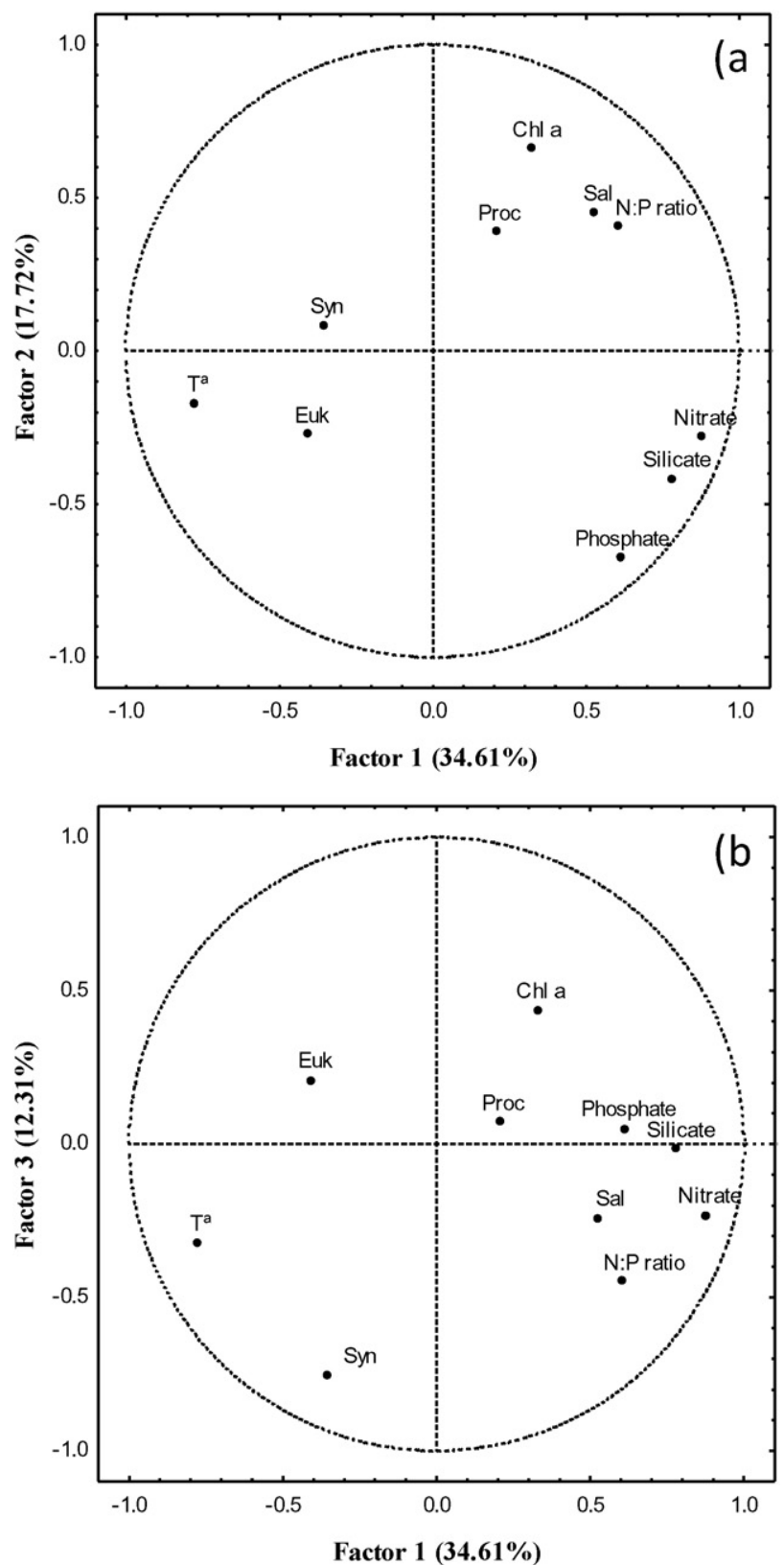

Fig. 5. Structure of the three factors, (a) Factor 1 vs. Factor 2 and (b) Factor 1 vs. Factor 3 extracted from the factorial analysis performed with the samples collected in the euphotic layer. T, temperature; Sal, salinity; chl a, chlorophyll a concentration; nitrate, nitrate concentration; phosphate, phosphate concentration; N:P ratio, molar ratio of nitrate to phosphate; Proc, abundance of Prochlorococcus; Syn, abundance of Synechococcus; Euk, abundance of picoeukaryotes.

Prochlorococcus in such areas in summer and late winter-early spring respectively, while it was relatively abundant in our study during the whole seasonal cycle. The annual variation of Synechococcus and picoeukaryotes showed marked differences among geographical sectors which did not match in any case the patterns described for other coastal areas. In Blanes Bay (western Mediterranean Sea) and the South Adriatic Sea, picoeukaryotes were reported as the dominant group in winter, while Synechococcus and Prochlorococcus dominated in summer and autumn or late summer, respectively (Gutiérrez-Rodríguez et al., 2011; Silovic et al., 2011). The cyanobacteria groups were also reported as dominant in summer in the Central Cantabrian Sea (NE Atlantic), in contrast to picoeukaryotes that dominated over the rest of the year (Calvo-Díaz et al., 2008). Due to differences among groups and sectors, the seasonal succession patterns of picophytoplankton were nonuniform in the Alboran Sea (Fig. 4).

\subsection{Relationship among environmental factors and distribution of} Synechococcus and Prochlorococcus

Regardless of the seasonal and vertical variability, our data indicate that the structure of the picophytoplankton community varied in the Alboran Sea following a longitudinal gradient with higher relative abundance of Prochlorococcus in BA, Synechococcus in ES and a mixed presence of the three groups in WS. The relatively high variability in physical-chemical conditions within and among geographical sector permits to assess the main factors driving the standing stock of picophytoplankton groups. According to the literature, light and temperature are the main factors determining the distribution of Prochlorococcus ecotypes in the water column. The presence of high (HL) and low-light (LL) adapted ecotypes have been described in the Atlantic and Pacific oceans (Johnson et al., 2006; Zinser et al., 2007), as well as in the Mediterranean Sea (Mella-Flores et al., 2011). In this work, Prochlorococcus showed a wide distribution along depth, with some maxima located close to the bottom of the euphotic layer (from 20 to $50 \mathrm{~m}$ depth), suggesting that both HL and LL ecotypes were present in the study area. HL ecotypes of Prochlorococcus show a wide range of growth conditions although its distribution is normally driven by temperature (Johnson et al., 2006; Mella-Flores et al., 2011; Zinser et al., 2007; Zwirglmaier et al., 2008). Prochlorococcus is known to dominate in warm $\left(>20^{\circ} \mathrm{C}\right)$ oligotrophic open oceanic waters, having limited growth below $12{ }^{\circ} \mathrm{C}$ (Partensky et al., 1999). However, high abundances of Prochlorococcus (higher than $10^{4}$ cells $\mathrm{mL}^{-1}$ ) have been described in relatively cold environments $\left(<15{ }^{\circ} \mathrm{C}\right)$ and warm oligotrophic waters of the South East Atlantic (Jameson et al., 2010; Zwirglmaier et al., 2008) and North West Atlantic (Zinser et al., 2007). In this study, abundance of Prochlorococcus in EL was higher at high salinity and N:P ratio and (to a less extent) colder waters, conditions that were more frequent during the first half part of the annual cycle. Nevertheless, variability in Prochlorococcus abundance was poorly explained by changes in temperature as demonstrated from the results of the factorial analysis. According to this analysis, Prochlorococcus in the northern Alboran Sea preferred high salinity and N:P ratio. These conditions are more frequently found in surface waters during the upwelling episodes that mainly affect the western sector of the Alboran Sea. This finding apparently contradicts the paradigm that Prochlorococcus grows optimally at low nutrient concentration because it cannot use nitrate, so it depends on its high surface area to volume ratio to access ammonium more efficiently or to take up organic nitrogen compounds at high rates (Worden et al., 2004). However, this hypothesis is partially disregarded by a recent study from Berube et al. (2015), which shows unequivocally that some strains of Prochlorococcus are indeed capable of growth using nitrate as the sole nitrogen source.

The factorial analysis also supports the segregation between Prochlorococcus and Synechococcus-picoeukaryotes. The latter tended to be more abundant in warmer, fresher and nutrient poorer waters, i.e. at surface levels under stratification conditions during summer. This pattern differs from other marine areas where high abundances of Synechococcus and picoeukaryotes have been described under colder and nutrient-rich conditions typical of surface coastal waters affected by upwellings (Echevarría et al., 2009; Partensky et al., 1996; Sherr et al., 2005). Similarly, comparatively high abundance of Synechococcus was also obtained in ES during winter when temperature was about $5{ }^{\circ} \mathrm{C}$ lower and salinity 0.5 higher compared to summer conditions. Accordingly, the samples obtained during winter in ES featured the lowest scores for the third factor extracted from the factorial analysis (Fig. 6). It is worth noting that $\mathrm{N}: \mathrm{P}$ ratio during this annual period in ES was significantly higher than during summer. Therefore the nutrient conditions under which the communities of Synechococcus grew during winter 


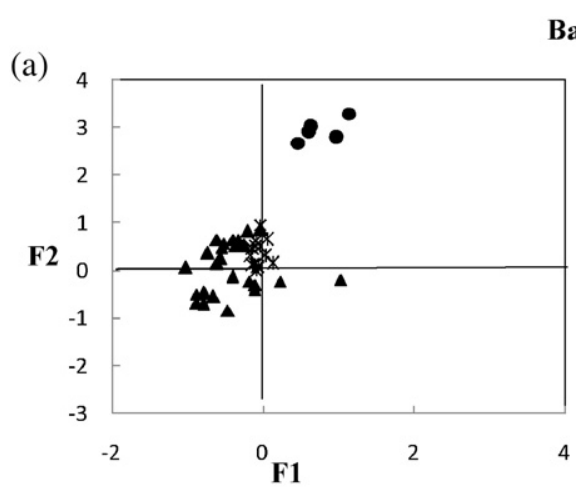

Bay of Algeciras
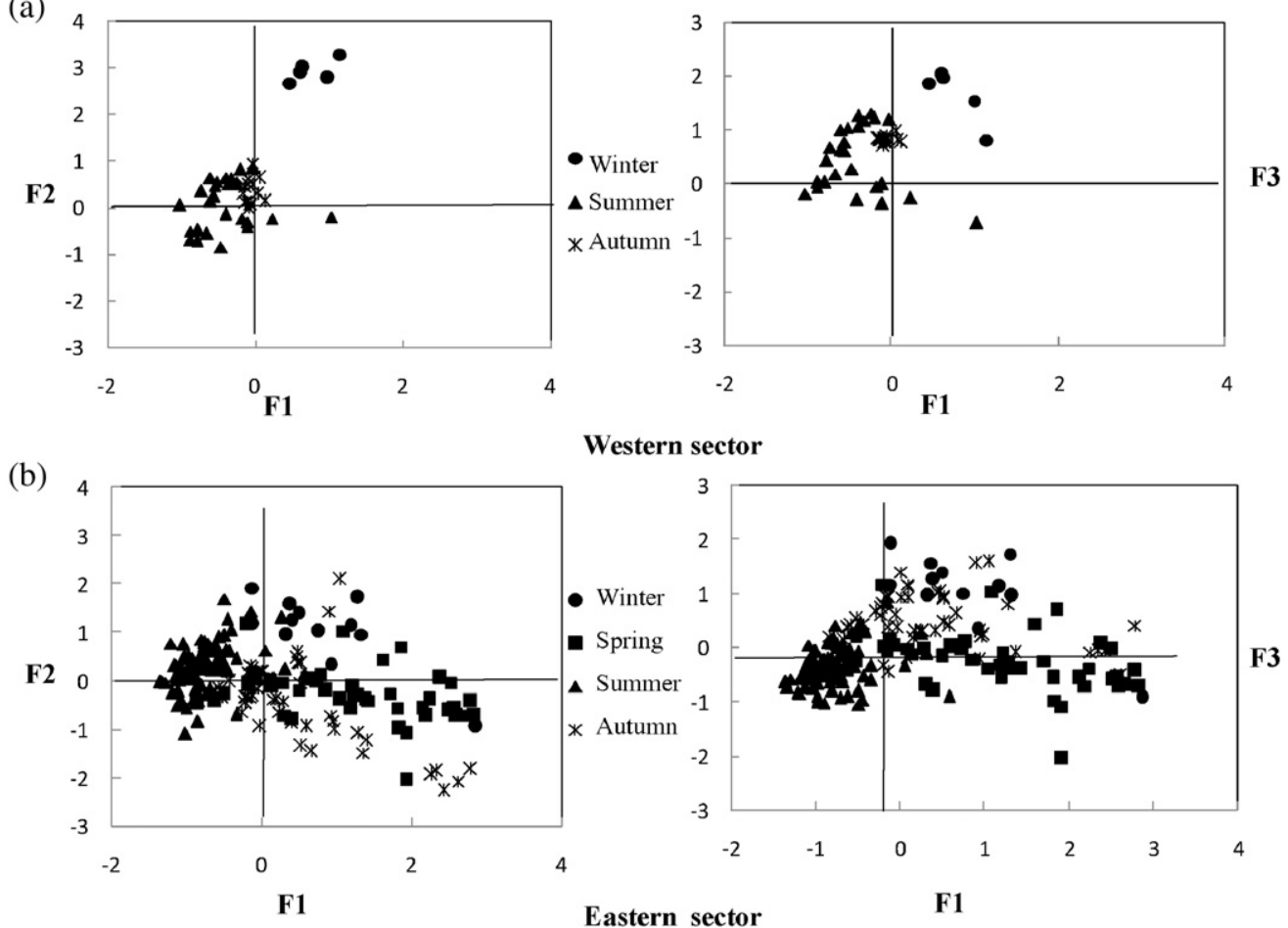

Western sector

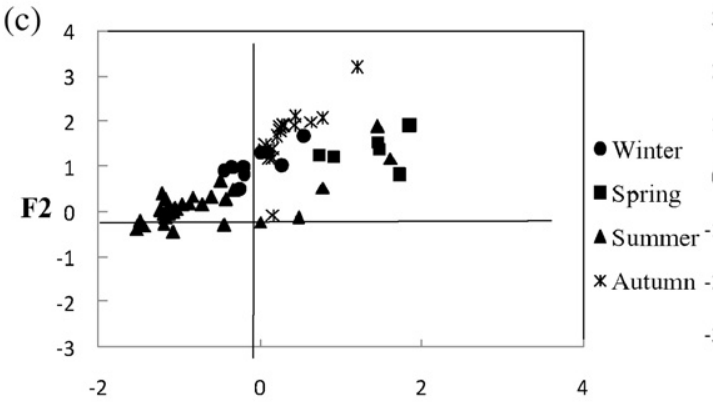

F1

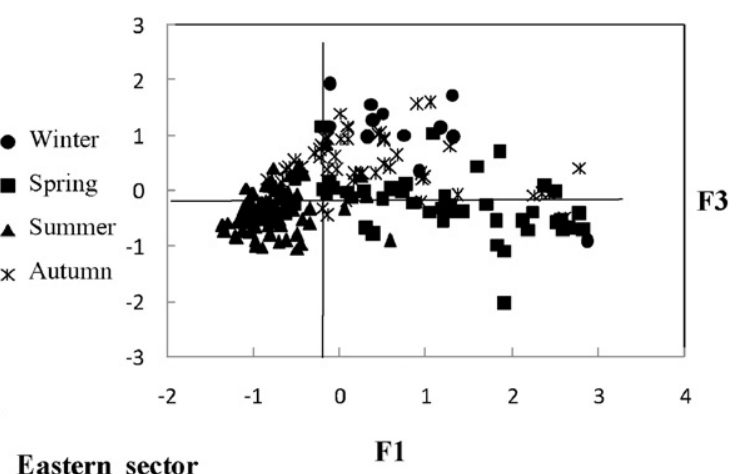

Eastern sector

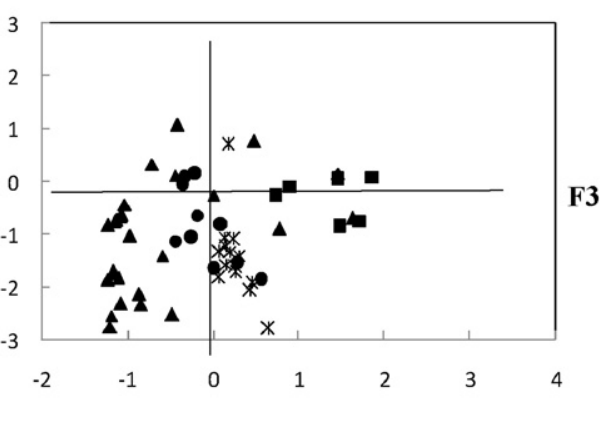

F1

Fig. 6. Bi-plot of the scores for the first three factors of each sample used in the factorial analysis: a) Bay of Algeciras, b) Western and c) Eastern sectors.

were also quite different in comparison to summer conditions. These findings may suggest the presence of at least two ecotypes of Synechococcus in the euphotic layer of the northern Alboran Sea: a summer ecotype that is widely distributed in the whole Alboran Sea and a winter ecotype adapted to lower temperature and higher nitrogen availability whose growth is favoured in ES. Genetic studies of Synechococcus worldwide demonstrate that this genus is genetically complex (Ahlgren and Rocap, 2012; Fuller et al., 2003; Huang et al., 2012; Rocap et al., 2002; Scanlan et al., 2009; Toledo and Palenik, 1997), with several clades widely distributed in the Mediterranean Sea (Mella-Flores et al., 2011). Clade I is usually observed in stable, low-nutrient conditions (Alonso-Sáez et al., 2008; Boras et al., 2009; Dufresne et al., 2008; Scanlan et al., 2009; Sohm et al., 2015; Toledo and Palenik, 2003; Zwirglmaier et al., 2008) typical of summer season in the northern Alboran Sea, or even in low phosphate environments (Ostrowski et al., 2010). In contrast, clades I and IV seem to be adapted to high nutrient/low temperature waters of the Mediterranean Sea (Mella-Flores et al., 2011). This wide range of physical-chemical conditions would make plausible that different clades dominated during the annual cycle at a given location, as it has been described for some coastal sites of the Pacific Ocean (Tai and Palenik, 2009). In concordance, our data may suggest a seasonal segregation of two or more Synechococcus ecotypes in the Eastern sector of the Alboran Sea. However, it is not clear why this presumed winter ecotype did not grow in BA where the physical framework was similar to ES. This discrepancy might be related to the grazing pressure that can be an important factor in structuring the picophytoplankton community (Stelfox-Widdicombe et al., 2000). Autotrophic picoplankton is mainly predated by heterotrophic nanoflagellates ranging from 3 to $5 \mu \mathrm{m}$ (Fenchel, 1986; Landry et al., 2011; Sherr and Sherr, 2002), which dominate the phytoplankton community in winter but are less abundant in summer in the Alboran Sea (Echevarría et al., 2009; Mercado et al., 2007). The annual succession of nanoflagellates and higher predation rates on Synechococcus than on Prochlorococcus (Christaki et al., 1999) may explain the horizontal variability of both groups observed in our study, which was contrary to previous observations in other marine areas (Campbell et al., 1998; Durand et al., 2001; Shalapyonok et al., 2001). Nevertheless, based on our data it cannot be discarded that the differences on nutrient uptake performance of Prochlorococcus and Synechococcus contributed to the longitudinal variation patterns observed in the Alboran Sea, as suggested by some authors (Worden et al., 2004).

\section{Conclusions}

The high variability of picoplankton abundance and composition observed in the northern Alboran Sea was related to the seasonal cycle and 
the permanent physical-chemical longitudinal gradient driven by the Atlantic-Mediterranean water exchange through the Strait of Gibraltar. The main longitudinal pattern is characterized by a more frequent dominance of Prochlorococcus in BA, co-dominance of picoeukaryotes and Synechococcus in WS and higher dominance of Synechococcus in ES. Our data demonstrate that Prochlorococcus and Synechococcus are capable of growing under a wide range of physical and chemical conditions, suggesting that at least two distinct ecotypes (HL/LL and winter/summer, respectively) in each genus grow in the Alboran Sea region. According to these results, the Alboran Sea seems to offer a unique physical framework, with a high variety of hydrodynamic features and environments, for the growth of several ecotypes of cyanobacteria. Given the lack of information on the dynamics of picophytoplankton communities, their importance on nutrient and carbon transfer to higher trophic levels in such highly dynamic regions (Morales and Anabalón, 2012) needs further investigation. Considering the genetic complexity of the diverse ecotypes (Dufresne et al., 2008; Garczarek et al., 2007), the molecular techniques are probably the most suitable approaches to resolve those questions. Molecular characterization of the eukaryotic picoplankton is still in early stages but is starting to reveal new lineages and a large phylogenetic diversity (Massana, 2011; Massana et al., 2004).

\section{Acknowledgements}

This research was funded by the National Secretariat of Research, Development and Innovation of the Spanish Government by means of the grants TROFOALBORAN (CTM2009-07776/MAR) and IPAF-ALB (CTM2012-37598-CO2-01).

\section{References}

Agawin, N., Duarte, C.M., Agustí, S., 2000. Nutrient and temperature control of the contribution of picoplankton to phytoplankton biomass and production. Limnol. Oceanogr. 45, 591-600.

Ahlgren, N.A., Rocap, G., 2012. Diversity and distribution of marine Synechococcus: multiple gene phylogenies for consensus classification and development of qPCR assays for sensitive measurement of clades in the ocean. Front. Microbiol. 3 (213), 1-24. http:// dx.doi.org/10.3389/fmicb.2012.00213.

Allen, J.T., Smeed, D.A., Tintore, J., Ruiz, S., 2001. Mesoscale subduction at the AlmeriaOran front: part 1. Ageostrophic flow. J. Mar. Syst. 30, 263-285.

Alonso-Sáez, L., Vázquez-Domínguez, E., Pinhassi, J., Cardelús, C., Sala, M.M., Lekunberri, I. Balague', V., Vila-Costa, M., Unrein, F., Massana, R., Sim'o, R., Gasol, J.M., 2008. Factors controlling the year-round variability in carbon flux through bacteria in a coastal marine system. Ecosystems 11, 397-409.

Baltar, F., Arístegui, J., Montero, M.F., Espino, M., Gasol, J.M., Herndl, G.J., 2009. Mesoscale variability modulates seasonal changes in the trophic structure of nano- and picoplankton communities across the NW Africa--Canary Islands transition zone. Prog. Oceanogr. 83, 180-188.

Berube, P.M., Biller, S.J., Kent, A.G., Berta-Thompson, J.W., Roggensack, S.E., RoacheJohnson, K.H., Ackerman, M., Moore, L.R., Meisel, J.D., Sher, D., Thompson, L.R. Campbell, L., Martiny, A.C., Chisholm, S.W., 2015. Physiology and evolution of nitrate acquisition in Prochlorococcus. ISME J. 9, 1195-1207.

Boras, J.J., Sara, M.M., Vázquez-Domínguez, E., Weinbauer, M.G., Vaqué, D., 2009. Annua changes of bacterial mortality due to viruses and prostits in an oligotrophic coasta environment (NW Mediterranean). Environ. Microbiol. 11, 1181-1193.

Bukata, R.P., Jerome, J.H., Kondratyev, K.Y., Pozdnyakov, D.V., 1995. Optical Properties and Remote Sensing of Inland and Coastal Waters. C.R.C. Press, Boca Raton, p. 362

Calvo-Díaz, A., Morán, X.A.G., Suárez, L.A., 2008. Seasonality of picophytoplankton chlorophyll a and biomass in the central Cantabrian Sea, southern Bay of Biscay. J. Mar. Syst. 72, 271-281.

Campbell, L., Landry, M.R., Constantinou, J., Nolla, H.A., Brown, S.L., Liu, H., 1998. Response of microbial community structure to environmental forcing in the Arabian Sea. Deep Sea Res. Part II 45, 2301-2325.

Campbell, L., Liu, H.B., Nolla, H.A., Vaulot, D., 1994. The importance of Prochlorococcus to community structure in the central North Pacific Ocean. Limnol. Oceanogr. 39 954-961.

Christaki, U., Giannakourou, A., Van Wamveke, F., Gregori, G., 2001. Nanoflagellate predation on auto- and heterotrophic picoplankton in the oligotrophic Mediterranean Sea. J. Plankton Res. 23, 1297-1310.

Christaki, U., Jacquet, S., Dolan, J.R., Vaulot, D., Rassoulzadegan, F., 1999. Growth and grazing on Prochlorococcus and Synechococcus by two marine ciliates. Limnol. Oceanogr. $44,52-61$.

Denis, M., Thyssen, M., Martin, V., Manca, B., Vidussi, F., 2010. Ultraphytoplankton basinscale distribution in the eastern Mediterranean Sea in winter: link to hydrodynamism and nutrients. Biogeosciences 7, 2227-2244.
Dufresne, A., Ostrowski, M., Scanlan, D.J., Garczarek, L., Mazard, S., Palenik, B.P., Paulsen, I.T., de Marsac, N.T., Wincker, P., Dossat, C., Ferreira, S., Johnson, J., Post, A.F., Hess, W.R., Partensky, F., 2008. Unravelling the genomic mosaic of a ubiquitous genus of marine cyanobacteria. Genome Biol. 9, R90.

Durand, M.D., Olson, R.J., Chisholm, S.W., 2001. Phytoplankton population dynamics at the Bermuda Atlantic time-series station in the Sargasso Sea. Deep Sea Res. Part II 48, 1983-2003.

Echevarría, F., Zabala, L., Corzo, A., Navarro, G., Prieto, D., Macías, D., 2009. Spatial distribution of autotrophic picoplankton in relation to physical forcings: the Gulf of Cádiz, Strait of Gibraltar and Alborán Sea study case. J. Plankton. Res. 31, 1339-1351.

Fenchel, T., 1986. The ecology of heterotrophic flagellates. Adv. Microb. Ecol. 9, 57-95.

Fuller, N.J., Marie, D., Partensky, F., Vaulot, D., Post, A.F., Scanlan, D.J., 2003. Clade-specific $16 \mathrm{~S}$ ribosomal DNA oligonucleotides reveal the predominance of a single marine Synechococcus clade throughout a stratified water column in the Red Sea. Appl. Environ. Microbiol. 69, 2430-2443.

Garczarek, L., Dufresne, A., Rousvoal, S., West, N.J., Mazard, S., Marie, D., Claustre, H., Raimbault, P., Post, A.F., Scanlan, D.J., Partensky, F., 2007. High vertical and low horizontal diversity of Prochlorococcus ecotypes in the Mediterranean Sea in summer. FEMS Microbiol. Ecol. 60, 189-206.

Gutiérrez-Rodríguez, A., Latasa, M., Scharek, R., Massana, R., Vila, G., Gasol, J.M., 2011. Growth and grazing rate dynamics of major phytoplankton groups in an oligotrophic coastal site. Estuar. Coast. Shelf Sci. 95, 77-87.

Huang, S., Wilhelm, S.W., Harvey, H.R., Taylor, K., Jiao, N., Chen, F., 2012. Novel lineages of Prochlorococcus and Synechococcus in the global oceans. ISME J. 6, 285-297.

Jacquet, S., Prieur, L., Avois-Jacquet, C., Lennon, J.-F., Vaulot, D., 2002. Short-timescale variability of picophytoplankton abundance and cellular parameters in surface waters of the Alboran Sea (western Mediterranean). J. Plankton Res. 24, 635-651.

Jameson, E., Joint, I., Mann, N.H., Mühling, M., 2010. Detailed analysis of the microdiversity of Prochlorococcus populations along a North-South Atlantic Ocean transect. Environ. Microbiol. 12, 156-171.

Johnson, Z.I., Zinser, E.R., Coe, A., McNulty, N.P., Woodward, E.M.S., Chisholm, S.W., 2006. Niche partitioning among Prochlorococcus ecotypes along ocean-scale environmental gradients. Science 311, 1737-1740.

Kana, T.M., Glibert, P., 1987. Effect of irradiances up to $2000 \mathrm{mE} \mathrm{m}^{-2} \mathrm{~s}^{-1}$ on marine Synechococcus WH 7803-II. Photosynthetic responses and mechanisms. Deep-Sea Res. 34, 497-516.

Lafuente, J.G., Cano, N., Vargas, M., Rubín, J.P., Hernández-Guerra, A., 1998. Evolution of the Alboran Sea hydrographic structures during July 1993. Deep-Sea Res. I 45, 39-65.

Landry, M.R., Selph, K.E., Taylor, A.G., Decima, M., Balch, W.M., Bidigare, R.R., 2011. Phytoplankton growth, grazing and production balances in the HNLC equatorial Pacific. Deep-Sea Res. II 58, 524-535.

Li, W.K.W., 1994. Primary productivity of prochlorophytes, cyanobacteria and eukaryotic ultraphytoplankton: measurements from flow cytometric sorting. Limnol. Oceanogr. 39, 169-175.

Li, W.K.W., Zohary, T., Yacobi, Z., Wood, A.M., 1993. Ultraphytoplankton in the eastern Mediterranean Sea: towards deriving phytoplankton biomass from flow cytometric measurements of abundance, fluorescence and light scatter. Mar. Ecol. Prog. Ser. 102, 79-87.

Liu, H., Suzuki, K., Minami, C., Saino, T., Watanabe, M., 2002. Picoplankton community structure in the subarctic Pacific Ocean and the Bering Sea during summer 1999. Mar. Ecol. Prog. Ser. 237, 1-14.

Marty, J.-C., Chiaverini, J., Pizay, M.D., Avril, B., 2002. Seasonal and interannual dynamics of nutrients and phytoplankton pigments in the western Mediterranean Sea at the DYFAMED time-series station (1991-1999). Deep-Sea Res. II 49, 1965-1985.

Massana, R., 2011. Eukaryotic picoplankton in surface oceans. Annu. Rev. Microbiol. 65, 91-11.

Massana, R., Balagué, V., Guillou, L., Pedrós-Alió, C., 2004. Picoeukaryotic diversity in an oligotrophic coastal site studied by molecular and culturing approaches. FEMS Microbiol. Ecol. 50, 231-243.

Mella-Flores, D., Mazrd, S., Humily, F., Partensky, F., Mahé, F., Bariat, L., Courties, C., Marie, D., Ras, J., Mauriac, R., Jeanthon, C., Bendif, E.M., Ostroswki, M., Scanlan, D.J., Garczarek, L., 2011. Is the distribution of Prochlorococcus and Synechococcus ecotypes in the Mediterranean Sea affected by global warming? Biogeosci. Discuss. 8, 4281-4330.

Mercado, J.M., Cortés, D., García, A., Ramírez, T., 2007. Seasonal and inter-annual changes in the planktonic communities of the northwest Alboran Sea (Mediterranean Sea). Prog. Oceanogr. 74, 273-293.

Mercado, J.M., Cortés, D., Ramírez, T., Gómez, F., 2012. Hydrological forcing masks the potential impact of nutrient release from diffuse sources in the NW coast of the Alboran Sea. Hydrobiologia 680, 91-107.

Minas, H.J., Coste, B., Le Corre, P., Minas, M., Raimbault, P., 1991. Biological and geochemical signatures associated with the water circulation through the Strait of Gibraltar and in western Alboran Sea. J. Geophys. Res. 96, 8755-8771.

Morales, C., Anabalón, V., 2012. Phytoplankton biomass and microbial abundances during the spring upwelling season in the coastal area off Concepcion, central-southern Chile: variability around a time series station. Prog. Oceanogr. 92, 81-91.

Morel, A., Ahn, Y.-H., Partensky, F., Vaulot, D., Claustre, H., 1993. Prochlorococcus and Synechococcus: a comparative study of their optical properties in relation to their size and pigmentation. J. Mar. Res. 51, 617-649.

Ostrowski, M., Mazard, S., Tetu, S.G., Phillippy, K., Johnson, A., Palenik, B., Paulsen, I.T., Scanlan, D.J., 2010. PtrA is required for coordinate regulation of gene expression during phosphate stress in a marine Synechococcus. ISME J. 4, 908-921.

Partensky, F., Blanchot, J., Lantoine, F., Neveux, J., Marie, D., 1996. Vertical structure of picoplankton at different trophic sites of the subtropical Atlantic Ocean. Deep-Sea Res. I 43, 1191-1213.

Partensky, F., Blanchot, J., Vaulot, D., 1999. Differential distribution and ecology of Prochlorococcus and Synechococcus in ocean waters: a review. In: Charpy, L., Larkum, A.W.D. (Eds.), Marine Cyanobacteria. Musée Océanographique, Monaco, pp. $457-475$. 
Petersen, T.W., Brent Harrison, C., Horner, D.N., van den Engh, G., 2012. Flow cytometric characterization of marine microbes. Methods 57, 350-358.

Preisendorfer, R.W., 1986. Secchi disk science: visual optics of natural waters. Limnol. Oceanogr. 31, 909-926.

Ramírez, T., Cortés, D., Mercado, J.M., Vargas-Yañez, M., Sebastián, M., Liger, E., 2005. Seasonal dynamics of inorganic nutrients and phytoplankton biomass in the NW Alboran Sea. Estuar. Coast. Shelf Sci. 65, 654-670.

Renault, L., Oguz, T., Pascual, A., Vizoso, G., Tintore, J., 2012. Surface circulation in the Alborán sea (Western Mediterranean) inferred from remotely sensed data. J. Geophys. Res. 117, C08009.

Reul, A., Rodríguez, V., Jiménez-Gómez, F., Blanco, J.M., Bautista, B., Sarhan, T., Guerrero, F., Ruíz, J., García-Lafuente, J., 2005. Variability in the spatio-temporal distribution and size-structure of phytoplankton across an upwelling area in the NW-Alboran Sea (W-Mediterranean). Cont. Shelf Res. 25, 589-608.

Ribes, M., Coma, R., Gili, J.M., 1999. Seasonal variation of particulate organic carbon, dissolved organic carbon and the contribution of microbial communities to the live particulate organic carbon in a shallow near-bottom ecosystem in the Northwestern Mediterranean Sea. J. Plankton Res. 21, 1077-1100.

Rocap, G., Distel, D.L., Waterbury, J.B., Chisholm, S.W., 2002. Resolution of Prochlorococcus and Synechococcus ecotypes by using $16 \mathrm{~S}-23 \mathrm{~S}$ ribosomal DNA internal transcribed spacer sequences. Appl. Environ. Microbiol. 68, 1180-1191.

Rodríguez, J., Blanco, J.M., Jiménez-Gómez, F., Echevarría, F., Gil, J., Rodríguez, V., Ruiz, J. Bautista, B., Guerrero, F., 1998. Patterns in the size structure of the phytoplankton community in the deep fluorescence maximum of the Alboran Sea (southwestern Mediterranean). Deep-Sea Res. I 45, 1577-1593.

Rodríguez, V., Blanco, J.M., Jiménez-Gómez, F., Rodríguez, J., Echevarría, F., Guerrero, F. 1997. Distribución espacial de algunos estimadores de biomasa fitoplanctónica y material orgánico particulado en el mar de Alborán, en condiciones de estratificación térmica (julio de 1993). Publ. Espec. Inst. Esp. Oceanogr. 24, 53-64.

Sánchez-Garrido, J.C., Lafuente, J.G., Sammartino, S., Naranjo, C., de los Santos, F.J., Álvarez Fanjul, E., 2014. Meteorologically-driven circulation and flushing times of the Bay of Algeciras, Strait of Gibraltar. Mar. Pollut. Bull. 80, 97-106.

Sarhan, T., García-Lafuente, J., Vargas, M., Vargas, J.M., Plaza, P., 2000. Upwelling mechanisms in the northwestern Alborán Sea. J. Mar. Syst. 23, 317-331.

Scanlan, D.J., Ostrowski, M., Mazard, S., Dufresne, A., Garczarek, L., Hess, W.R., Post, A.F., Hagemann, M., Paulsen, I., Partensky, F., 2009. Ecological genomics of marine picocyanobacteria. Microbiol. Mol. Biol. Rev. 73, 249-299.

Shalapyonok, A., Olson, L.J., Shalapyonok, L.S., 2001. Arabian Sea phytoplankton during southwest and Northeast Monsoons 1995: composition, size structure and biomass from individual cell properties measured by flow cytometry. Deep Sea Res. Part II $48,1231-1261$.

Sherr, E.B., Sherr, B.F., 2002. Significance of predation by protists in aquatic microbial food webs. Antonie Van Leeuwenhoek 81, 293-308.

Sherr, E.B., Sherr, B.F., Wheeler, P.A., 2005. Distribution of coccoid cyanobacteria and small eukaryotic phytoplankton in the upwelling ecosystem off the Oregon coast during 2001 and 2002. Deep-Sea Res. II 52, 317-330.

Sieburth, J.M.N., 1979. Sea Microbes. Oxford University Press, New York.

Silovic, T., Ljubesic, Z., Mihanovic, H., Olujic, G., Terzic, S., Jaksić, Z., Vilicic, D., 2011. Picoplankton composition related to thermohaline circulation: the Albanian boundary zone (southern Adriatic) in late spring. Estuar. Coast. Shelf Sci. 91, 519-525.
Siokou-Frangou, I., Christaki, U., Mazzocchi, M.G., Montresor, M., Ribera d'Alcalá, M. Vaqué, D., Zingone, A., 2010. Plankton in the open Mediterranean Sea: a review. Biogeosciences 7, 1543-1586.

Sohm, J.A., Ahlgren, N.A., Thomson, Z.J., Williams, C., Moffett, J.W., Saito, M.A., Webb, E.A Rocap, G., 2015. Co-occurring Synechococcus ecotypes occupy four major oceanic regimes defined by temperature, macronutrients and iron. ISME J. 1-13 http://dx.doi. org/10.1038/ismej.2015.115.

Stelfox-Widdicombe, C.E., Edwards, ES, Burkill, P. Sleigh, M.A, 2000. Microzooplankton grazing activity in the temperate and sub-tropical NE Atlantic: summer 1996. Mar. Ecol. Prog. Ser. 208, 1-12.

Tai, V., Palenik, B., 2009. Temporal variation of Synechococcus clades at a coastal Ocean Pacific monitoring site. ISME J. 3, 903-915.

Tintoré, J., Gomis, D., Alonso, S., Parrilla, G., 1991. Mesoscale dynamics and vertical motion in the Alborán Sea. J. Phys. Oceanogr. 21, 811-823.

Toledo, G., Palenik, B., 1997. Synechococcus diversity in the California current as seen by RNA polymerase (rpoC1) gene sequences of isolated strains. Appl. Environ. Microbiol. 63 (11), 4298-4303.

Toledo, G., Palenik, B., 2003. A Synechococcus serotype is found preferentially in surface marine waters. Limnol. Oceanogr. 48, 1744-1755.

Uitz, J., Stramski, D., Gentili, B., D'Ortenzio, F., Claustre, H., 2012. Estimates of phytoplankton class-specific and total primary production in the Mediterranean Sea from satellite ocean color observations. Glob. Biogeochem. Cycles 26, GB2024. http://dx.doi.org/ 10.1029/2011GB004055.

Vaulot, D., Courties, C., Partensky, F., 1989. A simple method to preserve oceanic phytoplankton for flow cytometric analyses. Cytometry 10, 629-635.

Vaulot, D., Eikrem, W., Viprey, M., Moreau, H., 2008. The diversity of small eukaryotic phytoplankton $(\leq 3 \mu \mathrm{m})$ in marine ecosystems. FEMS Microbiol. Rev. 32, 795-820.

Vaulot, D., Partensky, F., Neveux, J., Mantoura, R.F.C., Llewellyn, C.A., 1990. Winter presence of prochlorophytes in surface waters of the north western Mediterranean Sea. Limnol. Oceanogr. 35, 1156-1164.

Verity, P., Robertson, C.Y., Tronzo, C.R., Andrews, M.G., Nelson, J.R., Sieracki, M.E., 1992 Relationship between cell volume and carbon and nitrogen content of marine photosynthetic nanoplankton. Limnol. Oceanogr. 37, 1434-1446.

Worden, A.Z., Nolan, J.K., Palenik, B., 2004. Assessing the dynamics and ecology of marine picophytoplankton: the importance of the eukaryotic component. Limnol. Oceanogr. 49, 168-179.

Zinser, E.R., Johnson, Z.I., Coe, A., Karaca, E., Veneziano, D., Chisholm, S.W., 2007. Influence of light and temperature on Prochlorococcus ecotype distributions in the Atlantic Ocean. Limnol. Oceanogr. 52, 2205-2220.

Zohary, T., Brenner, S., Krom, M.D., Angel, D.L., Kress, N., Li, W.K.W., Neori, A., Yacobi, Y.Z. 1998. Build up of microbial biomass during deep winter mixing in a Mediterranean warm-core eddy. Mar. Ecol. Prog. Ser. 167, 47-57.

Zwirglmaier, K., Jardillier, L., Ostrowski, M., Mazard, S., Garczarek, L., Vaulot, D., Not, F., Massana, R., Ulloa, O., Scanlan, D.J., 2008. Global phylogeography of marine Synechococcus and Prochlorococcus reveals a distinct partitioning of lineages among oceanic biomes. Environ. Microbiol. 10, 147-161. 